\title{
Zooplankton communities in a large prealpine lake, Lake Constance: comparison between the Upper and the Lower Lake
}

\author{
Hans Bernd STICH, Martin PFEIFFER ${ }^{1)}$ and Gerhard MAIER*1) \\ Institute of Lake Research, State Institute for Environmental Protection Baden-Württemberg, Argenweg 50/1, 88085 Langenargen, \\ Germany \\ ${ }^{1)}$ Department of Experimental Ecology of Animals, University of Ulm, Albert-Einstein-Allee 11, 89069, Ulm, Germany \\ *e-mail corresponding author: gmaier.limnos@t-online.de
}

\begin{abstract}
The zooplankton communities of two basins of a large lake, Lake Constance, were compared during the years 2002 and 2003. The two basins differ in morphology, physical and chemical conditions. The Upper Lake basin has a surface area of $470 \mathrm{~km}^{2}$, a mean depth of 100 and a maximum depth of $250 \mathrm{~m}$; the Lower Lake basin has a surface area of $62 \mathrm{~km}^{2}$, a mean depth of only 13 and a maximum depth of $40 \mathrm{~m}$. Nutrient, chlorophyll-a concentrations and mean temperatures are somewhat higher in the Lower than in the Upper Lake. Total abundance of rotifers (number per $\mathrm{m}^{2}$ lake surface) was higher and rotifer development started earlier in the year in the Lower than in the Upper Lake. Total abundance of crustaceans was higher in the Upper Lake in the year 2002; in the year 2003 no difference in abundance could be detected between the lake basins, although in summer crustacean abundance was higher in the Lower than in the Upper Lake. Crustacean communities differed significantly between lake basins while there was no apparent difference in rotifer communities. In the Lower Lake small crustaceans, like Bosmina spp., Ceriodaphnia pulchella and Thermocyclops oithonoides prevailed. Abundance (number per $\mathrm{m}^{2}$ lake surface) of predatory cladocerans, large daphnids and large copepods was much lower in the Lower than in the Upper Lake, in particular during the summer months. Ordination with nonmetric multidimensional scaling (NMS) separated communities of both lakes along gradients that correlated with temperature and chlorophyll a concentration. Clutches of copepods were larger in the Lower than in the Upper Lake. No difference could be detected in clutch size of large daphnids between lake basins. Our results show that zooplankton communities in different basins of Lake Constance can be very different. They further suggest that the lack of large crustaceans in particular the lack of large predatory cladocerans in the Lower Lake can have negative effects on growth and reproduction of zooplanktivorous European whitefish, Coregonus lavaretus, which feeds highly selectively on large cladocerans and which is of great economic significance for the whole region. Another possibility could be that the lack of large Cladocera in the Lower Lake is a result of strong fish predation which could be a consequence of lake morphology.
\end{abstract}

Key words: zooplankton community, crustacean, Rotatoria, ordination, Lake Constance, Upper Lake, Lower Lake

\section{INTRODUCTION}

Lake Constance is one of the largest lakes in Central Europe and of great ecological and commercial significance. The lake can be divided into two main basins which differ considerably in morphology (Fig. 1) and slightly in physical and chemical conditions. The Upper Lake (Obersee) covers an area of $472 \mathrm{~km}^{2}$ and has a mean depth of 101 and a maximum depth of 250 $\mathrm{m}$. The lake changed from oligotrophic to mesoeutrophic during the first three quarters of this century and returned to oligotrophy during the last two decades (Gaedke 1998). This trophic "evolution" is due to man influence; nutrient load increase until the 1980's caused eutrophication and management for recovery resulted in oligotrophication (IGKB 2004). For example, maximum concentrations of total phosphorus in the epilimnion of the Upper Lake were $17 \mu \mathrm{g} \mathrm{l}^{-1}$ in the year 2002 and 21 $\mu \mathrm{g}^{-1}$ in the year 2003 and maximum chlorophyll- $a$ concentrations were $12 \mu \mathrm{g} \mathrm{l}^{-1}$ in 2002 and $6 \mu \mathrm{g} \mathrm{l}^{-1}$ in 2003 (IGKB 2003, 2004). The Lower Lake (Untersee) covers an area of $62 \mathrm{~km}^{2}$ and has a mean depth of $13 \mathrm{~m}$ and a maximum depth of $40 \mathrm{~m}$. Maximum total phosphorus concentrations in the epilimnion were $28 \mu \mathrm{g}$ $1^{-1}$ in the years 2002 and 2003 and maximum chlorophyll- $a$ concentrations were $13 \mu \mathrm{g} \mathrm{l}^{-1}$ in both years (IGKB 2003, 2004). The concentrations of total phosphorus and chlorophyll- $a$ in the Lower Lake are somewhat higher than in the Upper Lake which points to the higher trophy of the former. The higher trophy of the Lower Lake is also indicated by low oxygen concentrations $\left(\leq 1 \mathrm{mg} \mathrm{l}^{-1}\right)$ in the hypolimnion during summer (IGKB 2003, 2004). Both basins are interconnected via the "Seerhein", a $2.5 \mathrm{~km}$ long riverlike connection. The mean daily discharge from Upper to Lower Lake is about $29.4 \times 10^{6} \mathrm{~m}^{3} \mathrm{~d}^{-1}$ (Wagner et al. 2002), but due to climatic variations, discharge varies seasonally between $\mathrm{ca} 13.3 \times 10^{6} \mathrm{~m}^{3}$ $\mathrm{d}^{-1}$ and $c a 53.3 \times 10^{6} \mathrm{~m}^{3} \mathrm{~d}^{-1}$ (Lehn 1978). Zooplankton in the Upper Lake has been studied thoroughly (e.g. Berberovic 1990; Einsle 1969; 1978a, 1983a,b, 1987, 1988, 1989, 1990, 1997; Elster 1954; Elster \& Schwoerbel 1970; Gaedke 1992, 1995; Geller 1980, 1986; Gries \& Güde 1999; Hochstädter 2000; Lampert 


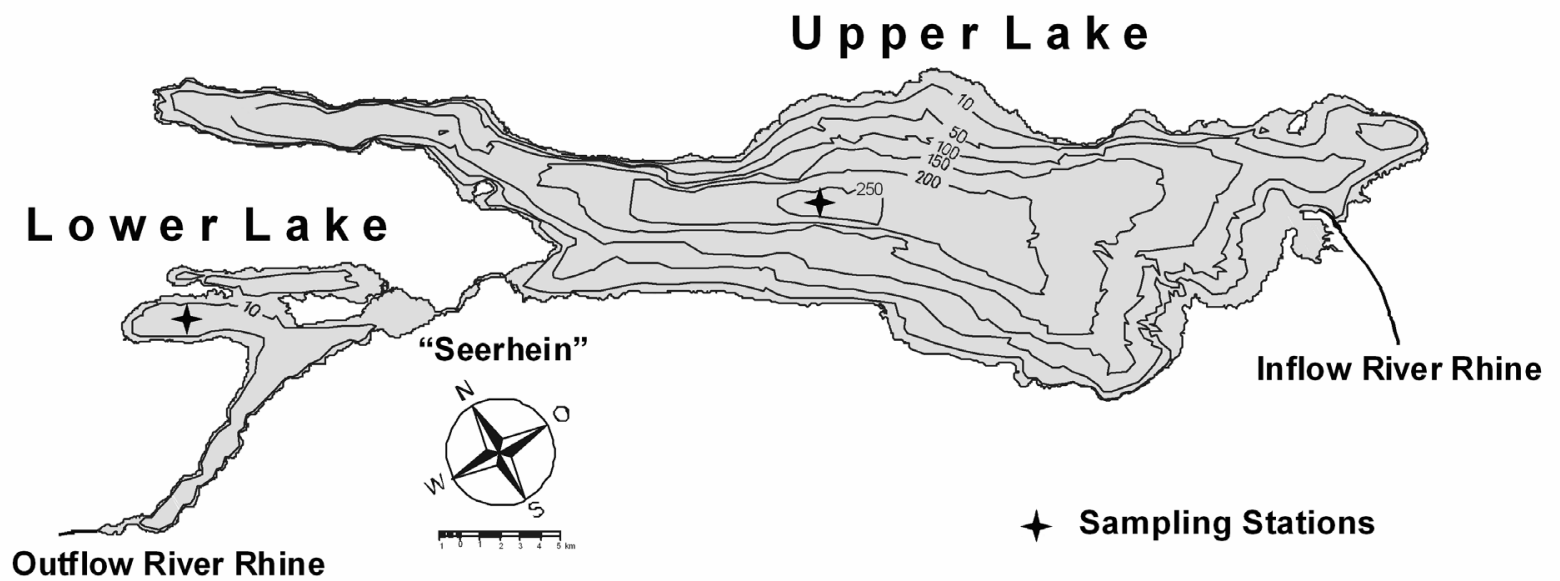

Fig. 1. Map of Lake Constance with sampling stations.

1978; Löffler et al. 2004; Muckle \& MuckleRottengatter 1976; Pauli 1990, 1991; Plaßmann et al. 1997; Sommer 1983; Straile 2000; Straile \& Geller 1998a, b; Straile \& Hälbich 2000; Stich 1989, 2004; Stich \& Lampert 1981, 1984; Walz et al. 1987; Weider \& Stich 1992; Weider et al. 1997). By contrast, only few studies exist about the zooplankton community in the Lower Lake (Auerbach \& Ritzi 1937; Auerbach \& Rottengattter 1960; Einsle 1965, 1978b, 1980; Elster \& Gessner 1935; Elster \& Einsele 1938; Hofmann 1991; Ritzi 1940) and there are very few which compare the zooplankton in both basins concomitantly (Fundel et al. 1998; Palmer et al. 2001). Recently, no investigation of the zooplankton of the Lower Lake has been accomplished. To close this gap we conducted a field study in the years 2002 and 2003 where we compared the zooplankton community in the Lower Lake with that in the Upper Lake. We expected that zooplankton communities of both lakes differ due to differences in abiotic and biotic conditions.

\section{METHODS}

Zooplankton samples were taken at the deepest places of the basins, at the station Fischbach-Uttwil in the Upper Lake and the station Zeller See in the Lower Lake (Fig. 1). Samples were taken from January 2002 to December 2003 in intervals of 1-2 weeks in the year 2002 and in intervals of 2-3 weeks in the year 2003. In total, 46 (rotifers) and 47 (crustaceans) samples were taken in the Upper Lake and 43 (rotifers) and 40 (crustaceans) in the Lower Lake. All samples were taken by vertical hauls from bottom to surface (Lower Lake) and from a depth of $30 \mathrm{~m}$ to surface (rotifers) and $100 \mathrm{~m}$ to surface (crustaceans) (Upper Lake). In the Upper Lake rotifer samples were confined to $0-30 \mathrm{~m}$ and crustaceans samples to $0-100 \mathrm{~m}$ because below $30 \mathrm{~m}$ few rotifers and below $100 \mathrm{~m}$ few crustaceans were present (Pauli 1990; Stich unpubl.). Rotifers were collected with 30 $\mu \mathrm{m}$ plankton net, crustaceans with a $100 \mu \mathrm{m}$ net. Sam- ples were preserved immediately in a $4-6 \%$ formalinsugar solution. In the laboratory samples were diluted in 250-1000 $\mathrm{ml}$ of water (dependent on zooplankton density); from this dilution aliquots of 10-25 ml were transferred into plankton chambers and counted under the inverted microscope (Zeiss IM 35; Oberkochen, Germany). If possible, 100 specimens were counted per taxon / species and each sampling date. Predatory cladocerans were counted separately; all individuals present in a sample (without dilution) were counted. Abundance was expressed as ind. $\mathrm{m}^{-2}$. We selected surface unit instead of a volume unit since this shows the actual number of individuals present under $1 \mathrm{~m}^{2}$.

Clutch sizes of dominant crustaceans were also analyzed. For each sampling date 10-20 egg bearing females per taxon were sorted out, their brood pouches (cladocerans) or egg sacs (copepods) dissected by pins and egg number counted. For quantitative comparison between the lake basins we subsumed different zooplankton taxa according to their size and / or feeding habit. The following size / feeding categories were distinguished: Large Daphnia $=$ D. hyalina and D. galeata; small Cladocera $=$ small daphnids $(D$. cucullata, $D$. parvula), Bosmina and Ceriodaphnia species; Cyclops spp. $=C$. abyssorum and $C$. vicinus; small cyclopoids $=$ Mesocyclops leuckarti and Thermocyclops oithonoides.

We examined the zooplankton communities of both lakes using PC-ORD computer programme (Version 4.25, McCune \& Mefford 1999). Nonmetric multidimensional scaling (NMS) was selected to investigate ordination of communities, which were evaluated by 86 samples of altogether 24 species. For ordination we used the Bray-Curtis distance, as recommended by McCune \& Grace (2002), and took quantitative data that were not normalized in order to keep the observed differences in abundance between the different species that otherwise would have been smoothed out. We used a random starting configuration with the number 4221 as a seed for the random number generator and with a 

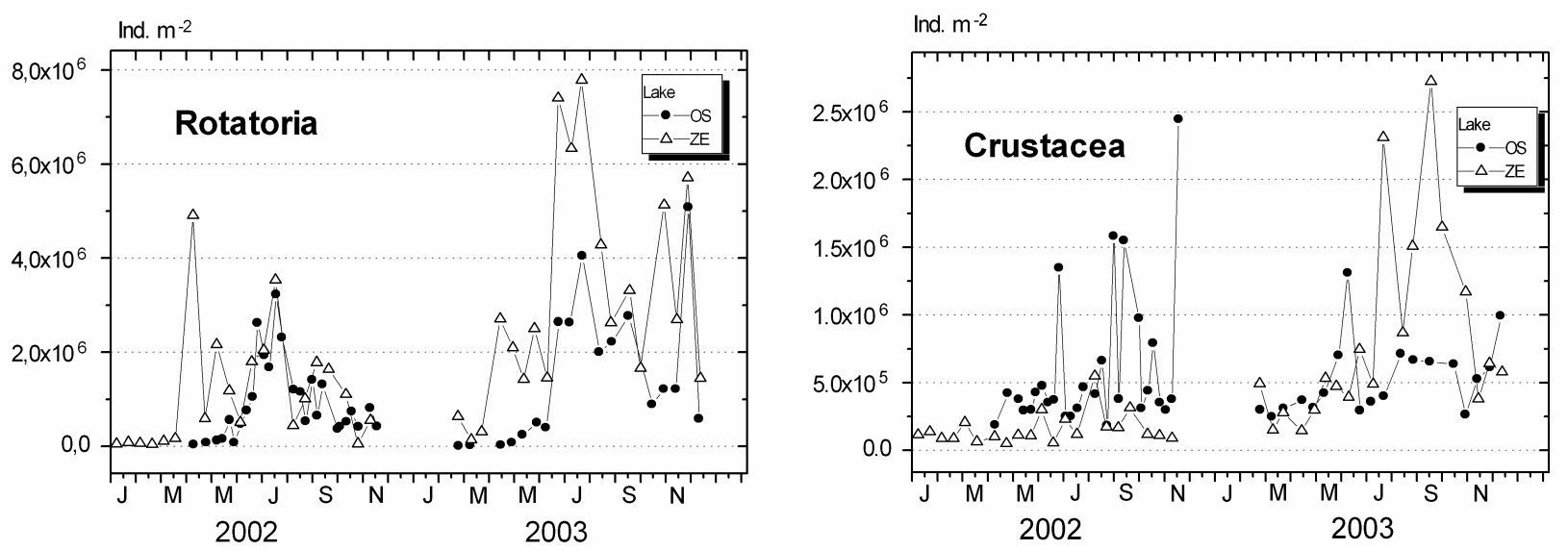

Fig. 2. Abundance of rotifers and crustaceans (sum of all taxa) during the years 2002 and 2003 in the Upper Lake (OS, station Fischbach Uttwil ) and Lower Lake (ZE, station Zeller See). Note different scale of Y axes.

maximum of 6 axes and 400 iterations. We employed the "autopilot" mode of PC-ORD to chose the best dimensionality: 40 runs were performed with real data and 50 with randomised data that provided the basis for a Monte Carlo test of significance to compare the final stress values. Additional dimensions were considered as useful if they reduced the final stress by 5 or more. The stability criterion was set to 0.000010 . PC-ORD calculates sample scores by NMS and automatically provides species scores computed by weighted averaging (Whittaker 1967).

Sample scores of NMS axes were then correlated (Spearman rank correlation) with temperature (mean temperature in the epilimnion) and chlorophyll- $a$ (mean concentration in $0-20 \mathrm{~m}$ ) to evaluate whether and how communities relate to these variables. Temperature and chlorophyll- $a$ were measured at the same time when zooplankton was collected. Chlorophyll- $a$ was determined by HPLC according to Schmid \& Stich (1995), temperature by a CTD 60-probe (Sea \& Sun). Similarly, we calculated Spearman rank correlations for the correlation of clutch sizes of selected taxa (see above) with environmental variables.

To evaluate differences between the NMS sample scores of Upper and Lower Lake and differences of abundances and clutch sizes of taxa between the lakes we used a non-parametric Wilcoxon-test. This test was selected because samples were taken at the same time in both lakes and because abundance and clutch size of zooplankton in the Upper Lake were mostly correlated with the same parameters in Lower Lake.

In the figures and graphs we used the abbreviations OS (abbreviation for Obersee / Upper Lake) and ZE (abbreviation for Zeller See / Lower Lake); ZE was used because Lower Lake samples were taken in the Zeller See (central part of the Lower Lake).

\section{RESULTS}

The total abundance of rotifers and crustaceans (sum of abundance of all taxa) are depicted in figure 2 .
Development of rotifers started earlier in the Lower lake in both years than in the Upper Lake and abundance of rotifers was higher in the Lower Lake than in the Upper Lake in particular in the year 2003 (Wilcoxon-test; year 2002: $Z=-2.40, P<0.02$; year 2003: $Z=-3.72, P$ $<0.0002)$. Abundance of crustaceans was higher in the Upper than in the Lower Lake in the year 2002 (Wicoxon-test; $Z=-3.18, P<0.001$ ). In 2003 no significant difference of crustacean abundance was observed between the lake basins (Wilcoxon-test; $Z=$ $1.25, \mathrm{P}=0.212 \mathrm{~ns}$ ) although in summer abundance in the Lower Lake surpassed that in the Upper Lake (Fig. 2). Both, abundance of rotifers and crustaceans in the Upper Lake was significantly positively correlated with abundance of rotifers and crustaceans in the Lower Lake (Spearman rang: Rotifers: $\mathrm{r}=0.632 ; \mathrm{n}=39$; $\mathrm{P}<0.0001$; crustaceans: $\mathrm{r}=0.408 ; \mathrm{n}=34 ; \mathrm{P}<0.008)$.

Zooplankton communities differed considerably between lakes (Tab. 1). Differences between the lakes were evident in composition of crustaceans. Small crustaceans, like Ceriodaphnia pulchella, Thermocyclops oithonoides and Daphnia cucullata were only present in the Lower Lake community. Larger forms, like D. hyalina, D. galeata, Cyclops spp., E. gracilis and predatory Cladocera were present in the Lower Lake but prevailed in the Upper Lake community. Community separation was clearly shown by NMS ordination that had a final stress of 10.21 and a final instability of 0.00001. A three dimensional solution was found after 172 iterations, the Monte Carlo test proved that all three axes had a smaller stress than a random solution ( $\mathrm{P}$ $<0.05)$. The $1^{\text {th }}$ axis represented $46 \%$ of the variance between ordination distances and distances in the original $n$-dimensional space, the $2^{\text {nd }}$ axis $0.27 \%$ of the variance and the $3^{\text {rd }} 0.12 \%$ (cumulative $\mathrm{r}^{2}=0.85$ for the correlation between the distances). Scores of the axes 1 and 2 were significantly negatively correlated with temperature (Spearman rank correlation axis $1: \mathrm{r}=-0.62, \mathrm{P}$ $<0.0001$; axis $2: \mathrm{r}=0.49, \mathrm{P}<0.0001$ ). Scores of axis 2 were significantly negatively correlated with chloro- 
Tab. 1. Abundant zooplankton-taxa in two basins of Lake Constance (Upper and Lower Lake) in the years 2002 and 2003.

\begin{tabular}{ll}
\hline ROTATORIA & CRUSTACEA \\
\hline Upper + Lower Lake & Upper + Lower Lake \\
Asplanchna priodonta (GOSSE) & cf. Eubosmina coregoni (BAIRD) \\
Ascomorpha cf. ecaudis (PERTY) & Bythotrephes longimanus (LEYDIG) \\
Brachionus angularis (GOSSE) & Daphnia galeata (SARS) \\
Brachionus diversicornis(DADAY) & Daphnia hyalina (LEYDIG) \\
Brachionus urecularis (MÜLLER) & Diaphanosoma brachyurum (LIEVIN) \\
Conochilus spp. & Leptodora kindti (FOCKE) \\
Collotheca spp. & Cyclops vicinus (ULJANIN) \\
Filinia longiseta (EHRENBERG) & Cyclops abyssorum (SARS) \\
Gastropus stylifer (IMHOF) & Eudiaptomus gracilis (SARS) \\
Kellicottia longispina (KELLICOTT) & Mesocyclops leuckarti (CLAUS) \\
Keratella cochlearis (GOSSE) & \\
Keratella quadrata (MÜLLER) & Only Lower Lake \\
Lecane sp. & \\
Notholca squamula (MÜLLER) & cf. Bosmina longirostris (O.F. MÜLLER) \\
Polyarthra spp. & Ceriodaphnia pulchella (SARS) \\
Pompholyx sulcata (HUDSON) & Daphnia cucullata (SARS) \\
Synchaeta spp. & Daphnia parvula (FORDYCE) \\
Trichocerca spp. & Thermocyclops oithonoides (SARS) \\
\hline
\end{tabular}
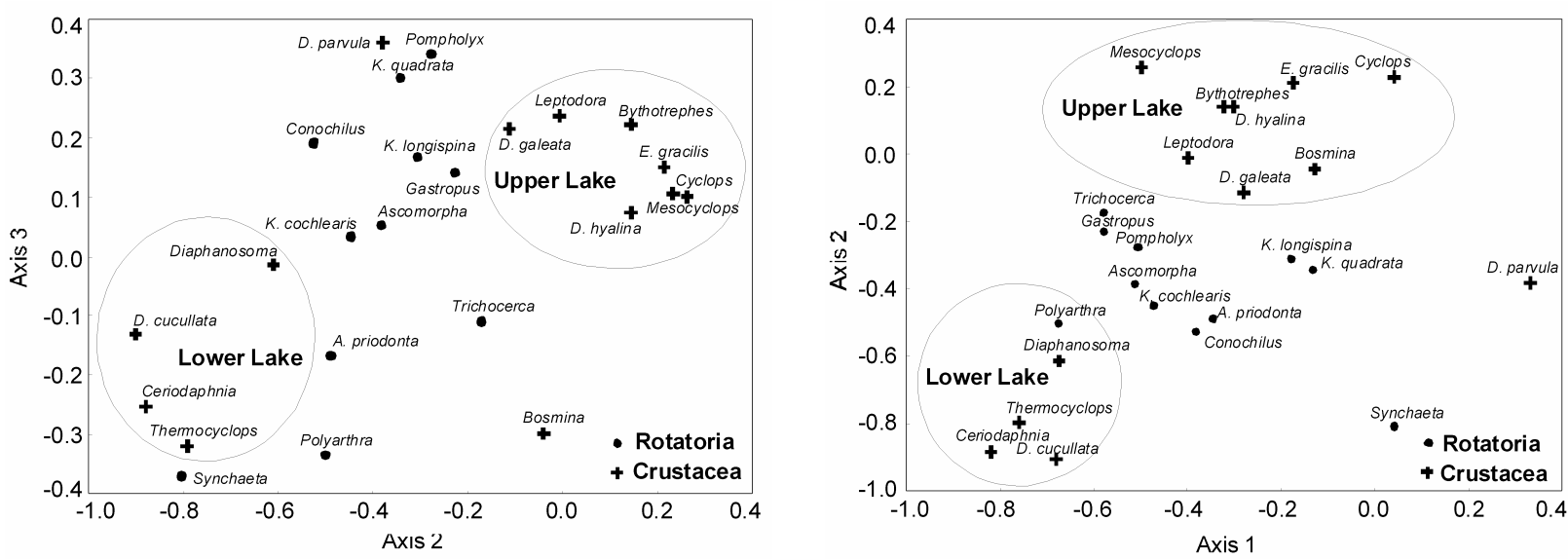

Fig. 3. Species scores of the NMS concerning zooplankton communities in two different basins of Lake Constance (Upper and Lower Lake). Communities were well separated along the different axis, which were negatively correlated with temperatures (axis 1) or chlorophyll- $a$ (axes 2, 3), respectively. Full species names are given in table 1.

phyll- $a$ (Spearman correlation $\mathrm{r}=-0.23, \mathrm{P}<0.05)$. Thus the Lower Lake had a zooplankton community that was significantly influenced by higher temperature and higher values of chlorophyll a (Fig. 3). Sample scores of axes 2 and 3 , but not axis 1 , differed significantly between lakes / lake basins (Wilcoxon Test, axis $2 \mathrm{Z}=$ $4.73 \mathrm{P}<0.0001$; axis $3 \mathrm{Z}=4.37 \mathrm{P}<0.0001$; axis $1 \mathrm{Z}=$ $1.55 \mathrm{p}=0.12$ ), thus confirming the contrast of the communities throughout our observation term (Fig. 4).

Abundance of predatory Cladocera was much higher in the Upper Lake than in the Lower Lake (Fig. 5; Tab. 2). Bythotrephes, for example, reached abundances of more than 3000 ind. $\mathrm{m}^{-2}$ in the Upper Lake while its abundance in the Lower Lake never surpassed 300 ind. $\mathrm{m}^{-2}$. Abundance of Leptodora was up to 7000 ind. $\mathrm{m}^{-2}$ in the Upper Lake and always below 1000 ind. in the Lower Lake. Thus peak abundances of predatory cladocerans under $1 \mathrm{~m}^{2}$ can be ten times higher in the Upper Lake than in the Lower Lake. Abundance of large daphnids (number of $D$. hyalina $+D$. galeata per $\mathrm{m}^{2}$ ) was also much higher in the Upper Lakes compared with the Lower Lake (Fig. 6; Tab. 2). In the Lower Lake large daphnids disappeared completely in the early summer months and did not re-appear until spring of the next year. Abundance of small Cladocera (number of Ceriodaphnia + Bosmina + small daphnids per $\mathrm{m}^{2}$ ), by contrast, was higher in the Lower Lake than in the Upper Lake, in particular in summer and autumn of the year 2003 (Fig. 6; Tab. 2). Abundance of large copepods (number of E. gracilis and Cyclops spp. per $\mathrm{m}^{2}$ ) was also higher in the Upper than in the Lower lake whereas no difference could be detected between lakes in abundance of small copepods (number of $M$. leuckarti $+T$. oithonoides per $\mathrm{m}^{2}$ ) although in summer 2003 abundance of small copepods was always higher in the Lower Lake (Fig 6; Tab. 2). Cyclops spp. disappeared from the pelagic during summer months in the Lower Lake but not in the Upper Lake. 


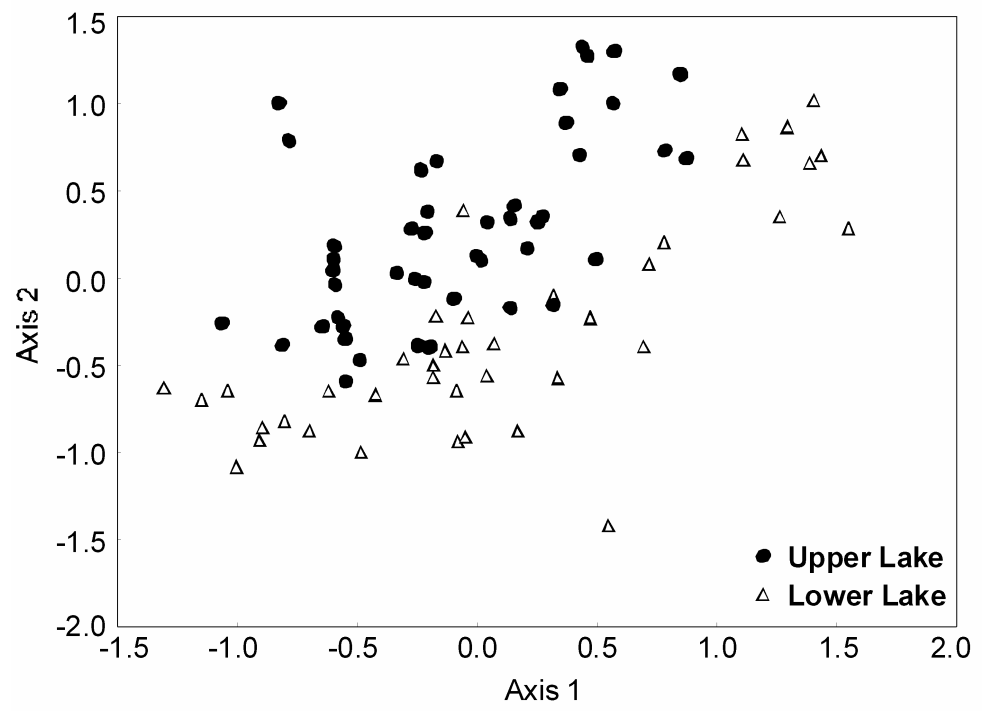

Fig. 4. Plot of axis 1 and 2 sample scores for different lake basins of Lake Constance.
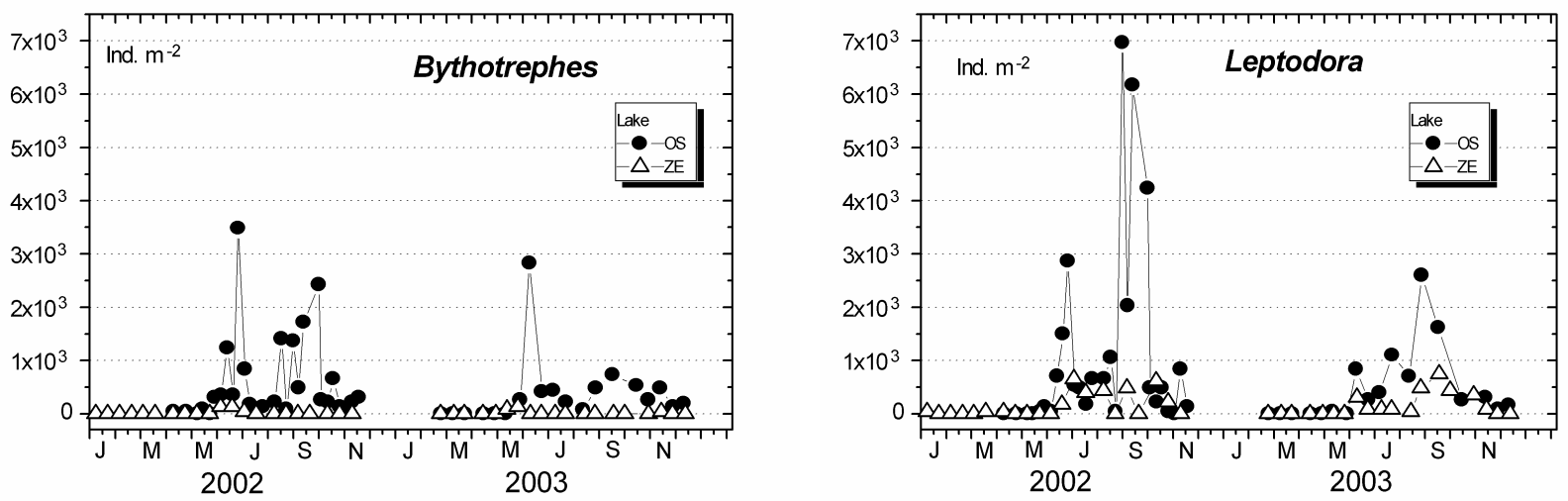

Fig. 5. Abundance of predatory cladocerans during the years 2002 and 2003 in the Upper (OS, station Fischbach Uttwil) and Lower Lake (ZE, station Zeller See) of Lake Constance.

Tab. 2. Results of the Wilcoxon-Tests concerning differences in abundance of prevailing taxa between lake basins of Lake Constance (OS = Upper Lake; ZE = Zeller See / Lower Lake).

\begin{tabular}{lccc}
\hline Taxon / Taxonomic group & $\mathrm{Z}$ & $\mathrm{P}$ & $\begin{array}{c}\text { Higher abundance / } \\
\text { Percentage }\end{array}$ \\
\hline Bythotrephes & -4.42 & 0.0001 & OS \\
Leptodora & -2.76 & 0.005 & OS \\
Large Daphnia & -4.03 & 0.0001 & OS \\
Small Cladocera & -2.74 & 0.006 & ZE \\
Eudiaptomus gracilis & -4.84 & 0.0001 & OS \\
Cyclops spp. & -3.67 & 0.0003 & OS \\
Small cyclopoids & -0.20 & $0.8(\mathrm{~ns})$ & - \\
Crustaceans total & -0.91 & $0.36(\mathrm{~ns})$ & - \\
Percentage Calanoids (vs Cyclopoids) & -4.83 & 0.0001 & OS \\
\hline
\end{tabular}



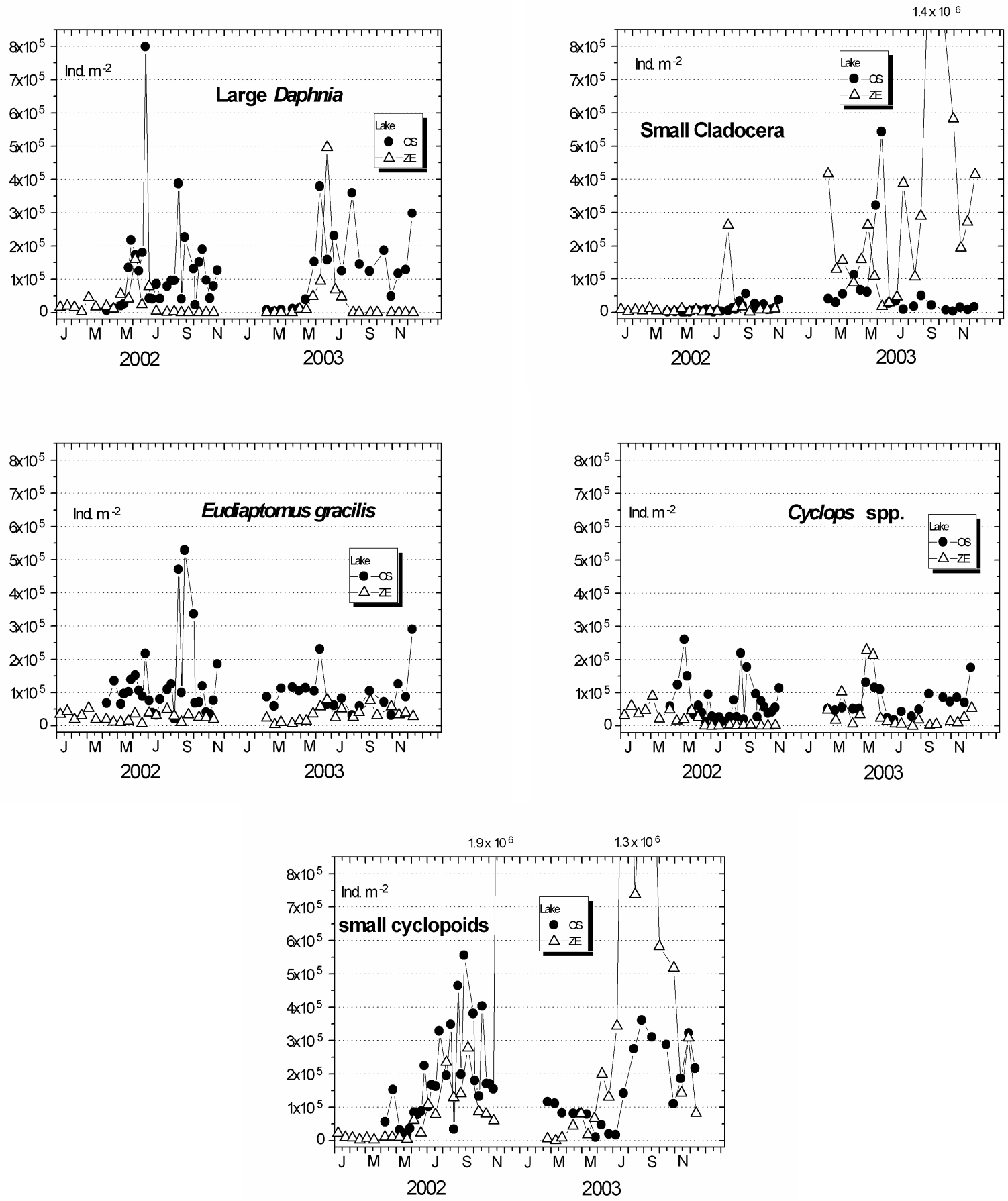

Fig. 6. Abundance of large Daphnia (D. galeata and D. hyalina), small Cladocera (small daphnids, Bosmina and Ceriodaphnia), large copepods (Eudiaptomus, Cyclops spp.) and small cyclopoid copepods (Mesocyclops and Thermocyclops) during the years 2002 and 2003 in the Upper (OS, station Fischbach Uttwil) and Lower Lake (ZE, station Zeller See) of Lake Constance. Cladoceran abundance refers to juveniles + adults, copepod abundance to copepodites and adults. 


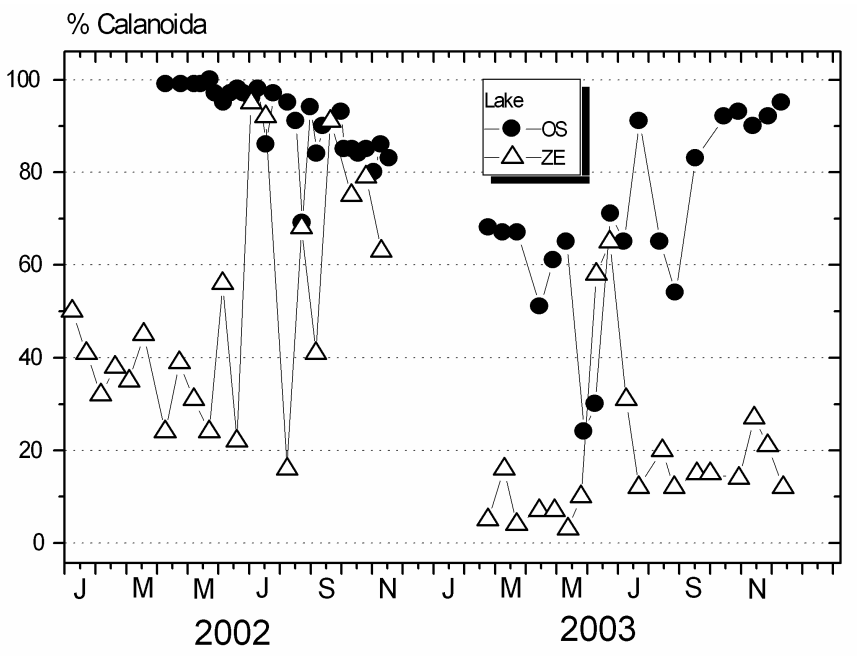

Fig. 7. Percentage of calanoids in relation to all copepods during the years 2002 and 2003 in the Upper (OS, station Fischbach Uttwil) and Lower Lake (ZE, station Zeller See) of Lake Constance.
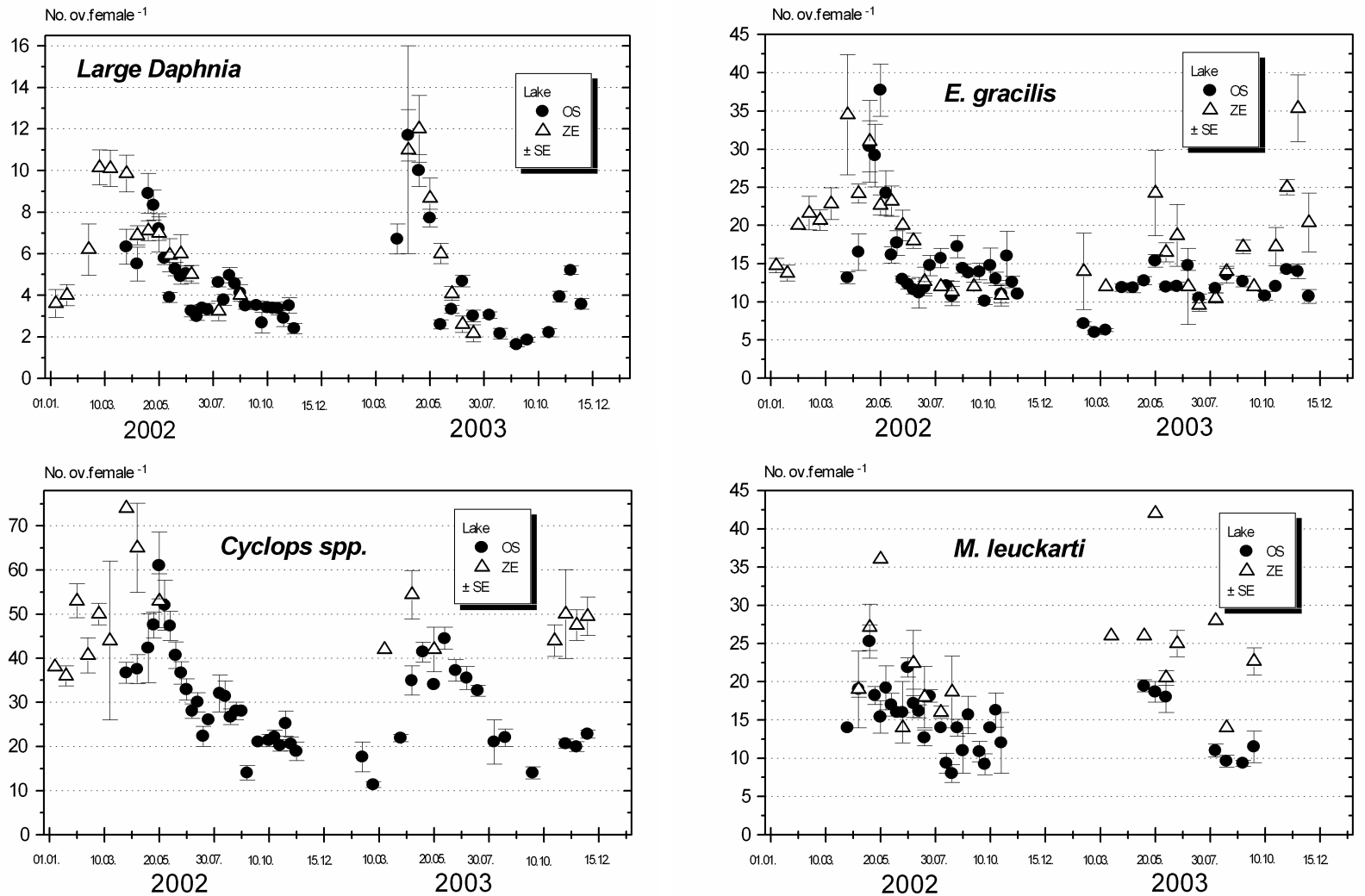

Fig. 8. Mean clutch size of dominant crustaceans during the years 2002 and 2003 in the Upper (OS, station Fischbach Uttwil) and Lower Lake (ZE, station Zeller See) of Lake Constance.

The calanoid-cyclopoid ratio ( $\%$ of calanoids relative to all copepods) also differed considerably between lakes being much higher in the Upper than in the Lower Lake (Fig. 7; Tab. 2). In the year 2002 always 80 or more than $80 \%$ of copepods were calanoids in the Upper Lake whereas in the Lower Lake mostly below $60 \%$ were calanoids. In the year 2003 , the calanoid- cyclopoid ratio was lower in both lakes than in the preceeding year. Clutches of crustaceans were largest in spring and comparatively low during summer (Fig. 8). No difference between lakes could be detected in clutch sizes of large daphnids (Fig. 8; Tab. 3). However, all copepods produced larger clutches in the Lower Lake than in the Upper Lake (Figs. 8; Tab. 3). 
Tab. 3. Results of the Wilcoxon-Test concerning differences in clutch size of prevailing taxa between lake basins of Lake Constance $(\mathrm{ZE}=$ Zeller See / Lower Lake).

\begin{tabular}{lccc}
\hline Taxon / Taxonomic group & $\mathrm{Z}$ & $\mathrm{P}$ & Bigger clutches \\
\hline Large Daphnia & -1.32 & $0.19(\mathrm{~ns})$ & - \\
Eudiaptomus gracilis & -2.75 & 0.006 & $\mathrm{ZE}$ \\
Cyclops spp. & -1.89 & 0.05 & $\mathrm{ZE}$ \\
Mesocyclops leuckarti & -3.08 & 0.002 & $\mathrm{ZE}$ \\
\hline
\end{tabular}

\section{DISCUSSION}

Our results show that zooplankton communities of the two different basins of Lake Constance, differ markedly and that differences between lakes are mainly based on differences between crustacean communities. Although we expected differences in species composition between the lakes we did not expect that differences were as evident as they are since both basins are part of one large lake with a high discharge from Upper Lake into Lower Lake. The comparatively low calanoid: cyclopoid ratio and the prevalence of small crustaceans confirms the somewhat higher trophy of the Lower Lake. A lower significance of calanoid copepods in comparison to cyclopoids in lakes with higher trophy has already been shown by several authors (Gliwicz 1969; Patalas 1972; Gannon \& Stemberger 1978; Karabin 1978; Rognerud \& Kjellberg 1984). That small Cladocera and cyclopoids prevail in the Lower Lake may originate from the fact that lakes with higher trophy generally have high concentration of bacteria which can be a food source for small crustaceans or early stages of small crustaceans (Brendelberger \& Geller 1985; Brendelberger 1991). This is supported by the high number of rotifers present in the upper lake which may also benefit from bacteria. Unfortunately, we have no information on bacteria in the Lower Lake.

In the Lower Lake, the development of rotifers started comparatively early in spring. This may originate from the earlier warming of this basin which can be associated with lake morphology (low depth). That ambient temperature influences the Lower Lake more than the Upper Lake is also supported by zooplankton development in the hot summer of 2003 where abundances in the Lower Lake were extremely high. Moreover, the results of the NMS indicate that Lower Lake community is greatly influenced by temperature. The stress of the NMS of 10.21 is at the upper border for a high-quality ordination (Clarke 1993), but gives a rather good explanation for ecological community data (McCune \& Grace 2002).

That small crustaceans prevail in the Lower Lake may have some negative effect on the fish stock. European whitefish (Coregonus lavaretus L.), a common zooplanktivorous fish in Lake Constance, feeds highly selectively on predatory cladocerans and large daphnids (Eckmann 1992; Eckmann et al. 2002; Morscheid \& Mayr 2002). Although the high abundance of small zooplankton in the Lower Lake may be beneficial for young whitefish (cf. Hartmann 1980, 1983), the low number of predatory cladocera and of large daphnids in particular during the summer may be insufficient to support growth and reproduction of adult fish. Another explanation for the lower number of large cladocerans per $\mathrm{m}^{2}$ lake surface in the Lower Lake could be strong fish predation. Diel vertical migration of large Cladocera in the deep Upper Lake could provide a refuge against fish predation; in the shallow Lower Lake no such migration is possible so that large Cladocera cannot evade fish. Thus the different morphology of both lake basins could result in a different predation pressure which in turn should differently shape the community structure. These are suggestions, however, which have to be checked by investigation of the fish stock.

The fact that copepods produced somewhat bigger clutches in the Lower Lake than in the Upper Lake and that cyclopoid copepods prevailed in the Lower Lake may originate from the high number of rotifers present. In particular late instars and adults of cyclopoid copepods are omnivorous to carnivorous and rotifers constitute a significant food for them (e.g. Plaßmann et al. 1997, Brandl \& Prazáková 2002).

We are aware that we compared zooplankton abundance of water columns with different extend. This shortcoming arises from the different morphology of lake basins. Nevertheless our results show that zooplankton communities of two basins of a large lake, Lake Constance, differ markedly with higher number of crustacean species and a prevalence of smaller forms in the Lower Lake basin. Although we expected differences between lake basins due to differences in morphology and slight differences in trophy we did not expect that differences are as great. We conclude that sampling at only one station is not sufficient to describe the zooplankton of a large lake. We expect differences in zooplankton composition and abundance between different stations of the same basin which should be investigated in the future. In particular the investigation of station sites which are situated along a gradient from the Rhine inlet to the Rhine outlet (that is from East to West) is recommended.

\section{REFERENCES}

Auerbach, M. \& M. Ritzi. 1937. Die Oberflächen- und Tiefenströme des Bodensees IV. Der Lauf des Rheinwassers durch den Bodensee in den Sommermonaten. Arch. Hydrobiol., XXXII: 409-433. 
Auerbach, M. \& G. Rottengatter. 1960. Untersuchungen über den Wasseraustausch der einzelnen Becken des Untersees (Bodensee). Schweiz. Z. Hydrol., 22: 599-640.

Berberovic, R. 1990. Elemental composition of two coexisting Daphnia species during the seasonal course of population development in Lake Constance. Oecologia (Berlin), 84: 340-350.

Brandl, Z. \& M. Prazáková. 2002. Impact of predation by cylopoid copepods (Copepoda: Cyclopoida) on zooplankton in a carp pond in Czech Republik. Acta Soc. Zool. Bohem., 66: 169-175.

Brendelberger, H. \& W. Geller. 1985. Variability of filtering structures in eight Daphnia species: mesh sizes and filtering areas. J. Plankton Res., 7: 473-486.

Brendelberger, H. 1991. Filter mesh size of cladocerans predicts retention efficiency for bacteria. Limnol. Oceanogr., 36: 884-894.

Clarke, K.R. 1993. Non-parametric multivariate analyses of changes in community structure. Austr. J. Ecol., 18: 117143.

Eckmann, R. 1992. In-situ Bestimmung der ZooplanktonTagesration adulter Felchen. DGL Report: 244-248.

Eckmann, R., M. Becker \& M. Schmid. 2002. Estimating food consumption by a heavily fished stock of zooplanktivorous Coregonus lavaretus. Trans. Am. Fish. Soc., 131: 946-955.

Einsle, U. 1965. Ökologische Studien an einer pelagisch lebenden Population von Diacyclops bicuspidatus (Crust. Cop.) Gewässer und Abwässer, 39/40: 102-117.

Einsle, U. 1969. Zur Frage der horizontalen Verteilung des Crustaceen-Planktons im Bodensee-Obersee. Gwf, 110: 108-111.

Einsle, U. 1978a. Qualitative und quantitative Änderungen im Crustaceenplankton des Bodensee-Obersee. Arch. Hydrobiol., 82: 300-315.

Einsle, U. 1978b. Das Crustaceenplankton im Gnadensee (Bodensee-Untersee) 1963/19, Schr. VG Bodensee, 96: 217-240.

Einsle, U. 1980. Weitere Untersuchungen 1976/1977 über das Crustaceenplanktons des Gnadensees (BodenseeUntersee). Schr. VG Bodensee, 98: 195-218.

Einsle, U. 1983a. Die Entwicklung und Männchenbildung der Daphnia-Population im Bodensee-Obersee 1956-1980. Schweiz. Z. Hydrol., 45: 321-332.

Einsle, U. 1983b. Long term changes in planktonic associations of crustaceans in Lake Constance and adjacent waters and their effects on competitive situations. Hydrobiologia, 106: 127-134.

Einsle, U. 1987. Zur Vertikalwanderung planktischer Copepoden im Bodensee-Obersee. Schweiz. Z. Hydrol., 49: 303-315.

Einlse, U. 1988. The long-term dynamics of crustacean communities in Lake Constance (Obersee, 1962-1986). Schweiz. Z. Hydrol., 50: 137-165.

Einsle, U. 1989. The identification of copepodid instars of some calanoid and cyclopoid copepods (Lake Constance). Crustaceana, 57: 79-87.

Einsle, U. 1990. Die horizontale Verteilung des Crustaceenplanktons im Bodensee-Obersee. Schr. VG Bodensee, 108: 247-257.

Einsle, U. 1997. Untersuchungen zum Auftreten von Acanthocyclops robustus (Crust. Cop.) im Bodensee-Obersee. Arch. Hydrobiol., 79: 382-396.

Elster, H.-J. 1954. Über die Populationsdynamik von Eudiaptomus gracilis Sars und Heterocope borealis Fischer im Bodensee-Obersee. Arch. Hydrobiol., Suppl. 15: 546-614.

Elster, H.J. \& F. Gessner. 1935. Die chemischen und biologische Sommerschichtung im Bodensee (Ober- und Untersee). Abbh. Geol.-palaeont. Inst. Greifswald.

Elster, H.J. \& W. Einsele. 1938. Beiträge zur Kenntnis der Hydrographie des Untersees (Bodensee). Int. Rev. ges. Hydrogr. Hydrobiol., 36: 241-284.
Elster, H.-J. \& J. Schwoerbel. 1970. Beiträge zur Biologie und Populationsdynamik der Daphnien im Bodensee. Arch. Hydrobiol. Suppl., 38: 18-72.

Fundel, B., H.B. Stich, H. Schmid \& G. Maier. 1998. Can phaeopigments be used as markers for Daphnia grazing in Lake Constance. J. Plankton Res., 20: 1449-1462.

Gaedke, U. 1992. The size distribution of plankton biomass in a large lake and its seasonal variability. Limnol. Oceanogr., 37: 1202-1220.

Gaedke, U. 1995. A comparison of whole-community and ecosystem approaches (biomass size distribution, food web analysis, network analysis, simulation models) to study the structure, function and regulation of pelagic food webs. J. Plankton Res., 17: 1273-1305

Gaedke, U. 1998. Functional and taxonomical properties of the phytoplankton community of large and deep Lake Constance: Interannual variability and response to reoligotrophication (1979-93). Arch. Hydrobiol. Spec. Issues Advanc. Limnol. 53: 119-141

Geller, W. 1980. Stabile Zeitmuster in der Planktonsukzession des Bodensees (Überlinger See). Verh. Ges. Ökol., 8: 363-383.

Geller, W. 1986. Diurnal vertical migration of zooplankton in a temperate great lake (L. Constance): a starvation avoidance mechanism. Arch. Hydrobiol. Suppl. (Monogr. Beitr.), 74, 11-60.

Gannon, J.E. \& R.S. Stemberger. 1978. Zooplankton (especially crustaceans and rotifers) as indicators of water quality. Trans. Am. Micros. Soc., 97: 16-35.

Gliwicz, Z. 1969. Studies on the feeding of pelagic zooplankton in lakes with varying trophy. Ekol. Pol., 17: 81-83.

Gries, T. \& H. Güde. 1999. Estimates of the nonconsumptive mortality of mesozooplankton by measurement of sedimentation loses. Limnol. Oceanogr., 44: 459-465.

Hartmann, J. 1980. Planktische Nahrung von Felchenlarven (Coregonus lavaretus) im Bodensee. A. Fisch.-Ztg., 30: 81-83.

Hartmann, J. 1983. Two feeding strategies of young fishes. Arch. Hydrobiol., 96: 496-509.

Hochstädter, S. 2000. Seasonal changes of C:P ratios of seston, bacteria, phytoplankton and zooplankton in a deep mesotrophic lake. Freshwat. Biol., 44: 453-463.

Hofmann, W. 1991. The late-glacial/holocene Bosmina (Eubosmina) fauna of Lake Constance (Untersee) (FRG): traces of introgressive hybridization. Hydrobiologia, 225: 81-85.

IGKB. 2003. Limnologischer Zustand des Bodensees. Iber. Int. Gewässerschutzkomm. 31 pp.103 (ISSN 1011-1271).

IGKB. 2004. Limnologischer Zustand des Bodensees. Iber. Int. Gewässerschutzkomm. 31 pp.75 (ISSN 1011-1271).

Karabin, A. 1983. Ecological characteristics of lakes in Northeastern Poland versus their trophic gradient. VII. Variations in the quantitative and qualitative structure of the pelagic zooplankton (Rotatoria and Crustacea) in 42 lakes. Ekol. Pol., 31: 383-409.

Lampert, W. 1978. Climatic conditions and planktonic interactions as factors controlling the regular succession of spring algal bloom and extremly clear water in Lake Constance. Verh. Internat. Verein Limnol., 20: 969-974.

Lehn, H. 1978. Vom Abfluß des Bodensee-Obersees. Verh. Ges. Ökologie: 163-173.

Löffler, A., J. Wolinska, B. Keller, K.-O. Rothhaupt \& P. Spaak. 2004. Life history patterns of parental and hybrid Daphnia differ between lakes. Freshwat. Biol., 49: 13721380.

McCune, B. \& M. J. Mefford. 1999. Multivariate Analysis of Ecological Data,Version 4.25 MjM Software, Gleneden Beach, Oregon, U.S.A.

McCune, B. \& J.B. Grace, 2002. Analysis of ecological communities. MjM Software Design, Gleneden Beach, Oregon USA: $300 \mathrm{pp}$. 
Morscheid, H. \& C. Mayr. 2002. Supply and demand - the interplay of vertical distribution of European whitefish (Coregonus lavaretus L.) and zooplankton in Lake Ammersee. Arch. Hydrobiol. Spec. Issues Advanc. Limnol., 57: 411-421.

Muckle, R. \& G. Muckle-Rottengatter. 1976. Einige Tabellen und Bemerkungen zur Soziologie des Crustaceenplanktons im Überlinger See (Bodensee-Obersee). Arch. Hydrobiol., 78: 415-455.

Palmer, A., H.B. Stich \& G. Maier. 2001.Distribution patterns and predation risk of the coexisting cladocerans Bythotrephes longimanus and Leptodora kindtii in a large lake Lake Constance. Hydrobiologia, 442: 301-307.

Patalas, K. 1972. Crustacean plankton and eutrophication of St. Lawrence Great Lakes. J. Fish. Res. Bd. Can., 29: $1451-1462$

Pauli, H.-R. 1990. Seasonal succession of rotifers in large lakes. In: Tilzer, M.M. \& C. Serruga (Eds), Large lakes; ecological structure and function. Springer Verlag: 459474.

Pauli, H.R. 1991. Estimates of rotifer productivity in Lake Constance: A comparison of methods. Verh. Internat.Verein Limnol., 24: 850-853.

Plaßmann, T., G. Maier \& H. B. Stich. 1997. Predation impact of Cyclops vicinus on the rotifer community in Lake Constance in spring. J. Plankton Res., 19: 1069-1079.

Ritzi, M. 1940. Hydrographische, biologische und fischereibiologische Untersuchungen im Untersee. 2. Daphnia longispina und Daphnia cucullata (Phyllopoda) im Gnadensee, Beitr. Naturtkund. Forschung Südwestdeutschland, 5: 61-76.

Rognerud, S. \& G. Kjellberg. 1984. Relationships between phytoplankton and zooplankton biomass in large lakes. Verh. Internat. Verein. Limnol., 22: 666-671.

Schmid, H. \& H. B. Stich. 1995. HPLC-analysis of algal pigments: comparison of columns, column properties and eluents. J. Appl. Phycol., 7: 487-494.

Sommer, U. 1983. Light stratification and zooplankton as controlling factors for the spring development of phytoplankton in Lake Constance. Schweiz. Z. Hydrol., 45: 394404.

Stich, H. B. 1989. Seasonal changes of diel vertical migration of crustacean plankton in Lake Constance. Arch. Hydrobiol., 3 (Suppl. 83): 355-405.

Received: March 2005

Accepted: August 2005
Stich, H.B. 2004. Back again: the reappearance of Diaphanosoma brachyurum in Lake Constance. Arch. Hydrobiol., 159: 423-431.

Stich, H. B. \& W. Lampert. 1981. Predation evasion as an explanation of diurnal vertical migration by zooplankton. Nature, 293: 396-398.

Stich, H.B. \& W. Lampert. 1984. Growth and reproduction of migrating and non-migrating Daphnia species under simulated food and temperature conditions of diurnal verical migration. Oecologia (Berlin), 61: 193-196.

Straile D. \& W. Geller. 1998a. The response of Daphnia to changes in trophic status and weather patterns: a case study from Lake Constance. ICES Journal of Marine Sciences, 55, 775-782.

Straile, D. \& W. Geller. 1998b. Crustacean zooplankton in Lake Constance from 1920 to 1995: response to eutrophication and re-oligotrophication. Arch. Hydrobiol. Spec. Issues Advanc. Limnol., 53: 255-274.

Straile, D. 2000. Meteorological forcing of plankton dynamics in a large and deep continental European lake. Oecologia, 122: $122-44$.

Straile, D. \& A. Hälbich. 2000. Life history and multiple antipredator defenses of invertebrate pelagic predator, Bythotrephes longimanus. Ecology, 81: 150-163.

Wagner, G.H., G. Schröder \& J. Gurtz. 2002. A model approach for in- and outflow calculation of Upper Lake Constance. Limnologica, 32: 27-32.

Walz, N., H.-J. Elster. \& M. Mezger. 1987. The development of the rotifer community structure in Lake Constance during its eutrophication. Arch. Hydrobiol. Suppl. (Monogr.Beitr.), 74: 452-487.

Weider, L.J. \& H.B. Stich. 1992. Spatial and temporal heterogeneity of Daphnia in Lake Constance; intra- and interspecific comparisons. Limnol. Oceanogr., 37(6): 13271334.

Weider, J.L., W. Lampert, M. Wessels, J.K. Colbourne \& P. Limburg. 1997. Long-term genetic shifts in a microcrustacean egg bank associated with anthropogenic changes in the Lake Constance ecosystem. Proc. R. Soc. Lond. B, 264: 1613-1618.

Whittaker, R.H. 1967. Gradient analysis of vegetation. Biol. Rev., 42: 207-264. 